بررسى هدررفت خاك در كرتهاى كوجى حاوى خاكهاى با بافت مختلف در

رخدادهاى ييايى باران شبيهسازى شده

على رضا واعظى " و حيدر حسنزاده

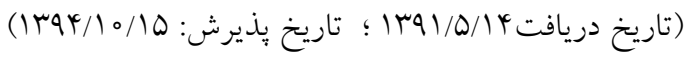

حكيده

آكاهى از تغييرات خصوصيات خاك از رخدادى به رخداد ديخر، براى تعيين دورههاى بحرانى حساسيت خاك به فر آيندهاى فرسايش حائز

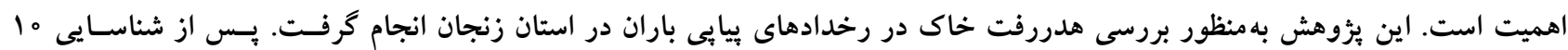

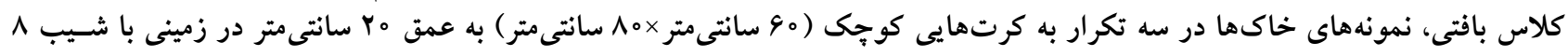

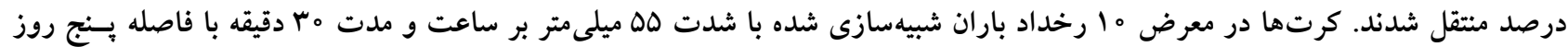

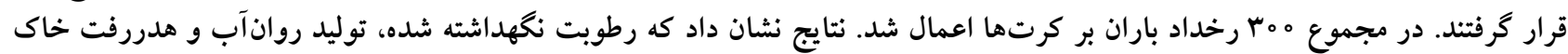

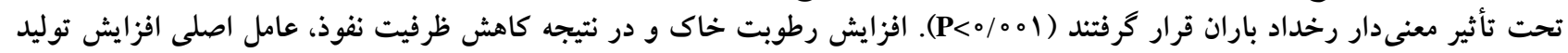

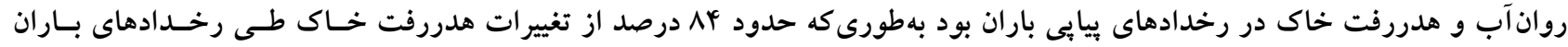

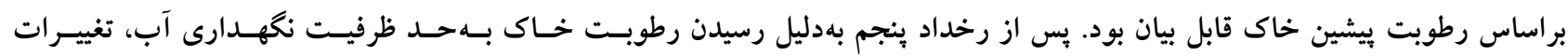

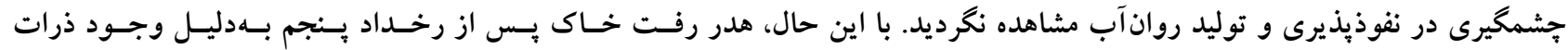

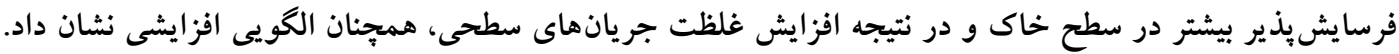

وازههاى كليدى: باران شبيهسازى شده، رطوبت بيشين خاك، روانآب، نفوذيذيرى خاك، فرآيندهاى فرسايش خاك 


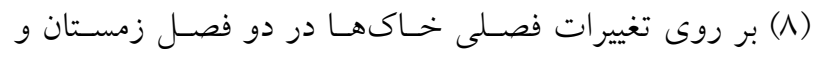

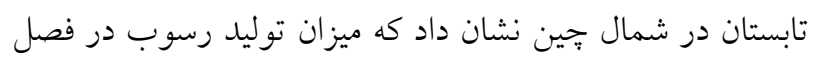

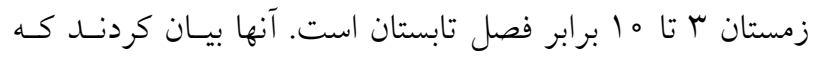

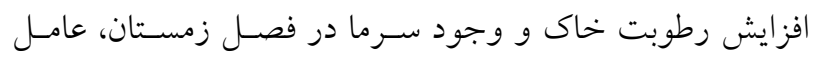

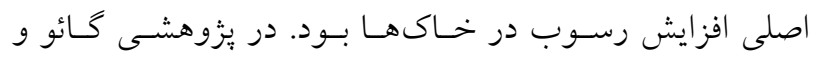

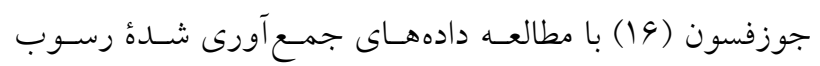

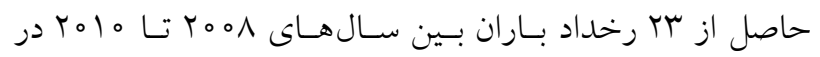

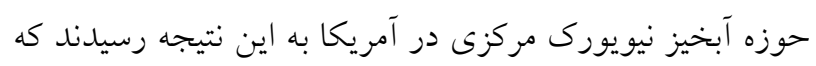

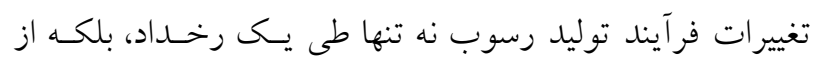

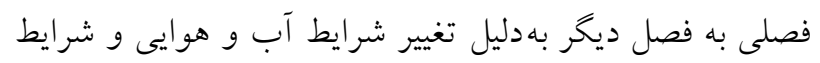

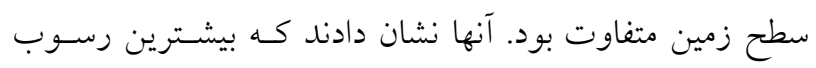

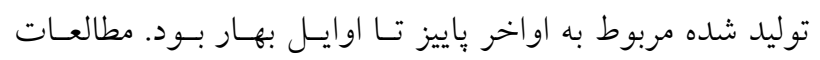

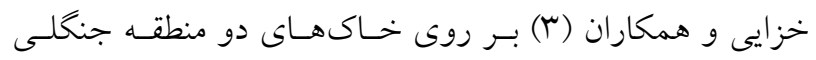

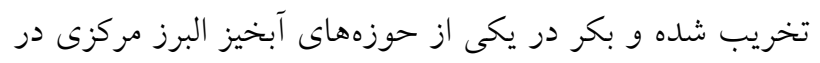

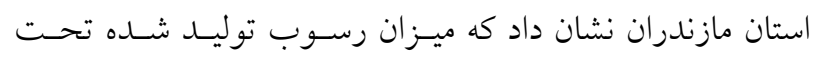

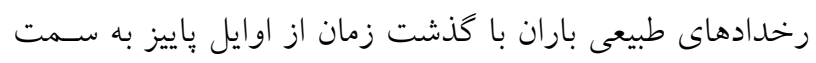

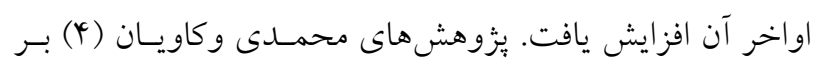

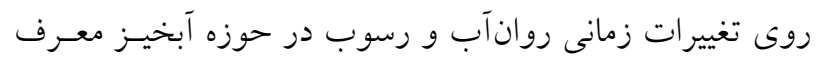

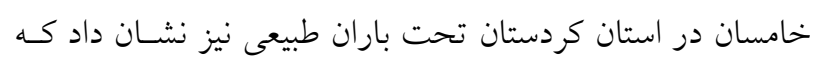

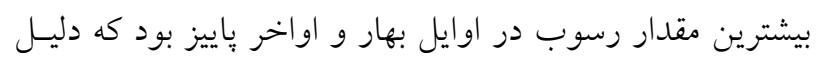

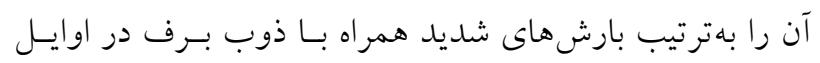
بهار و فرسايشيذيرى بيشتر خاك در اواخر باييز بيان كردند.

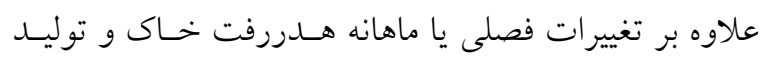

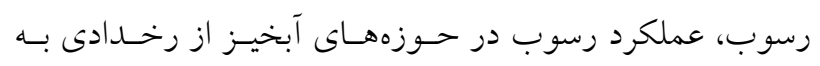

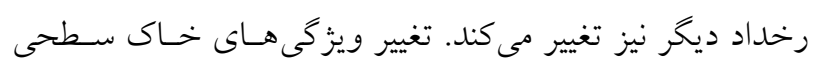

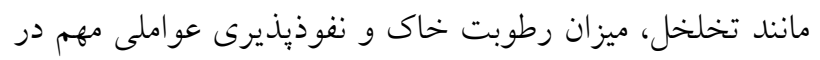

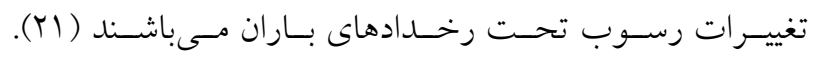

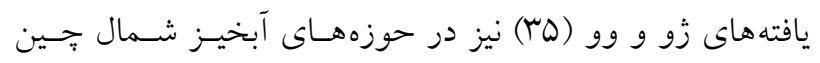

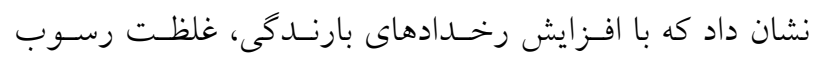

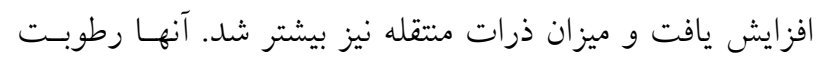

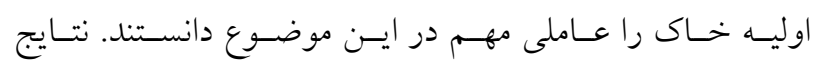

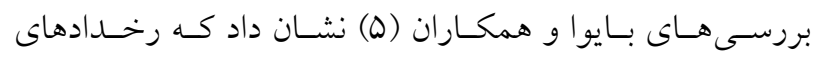

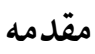

فرسايش آبى يك فر آيند سه مرحلهاى شـامل جداسـازى ذرات

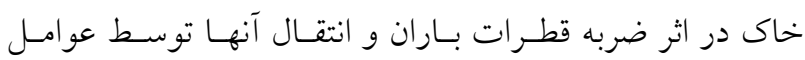

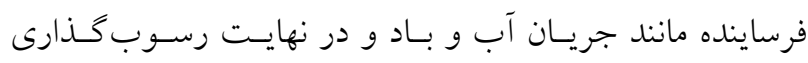

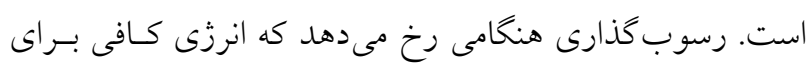

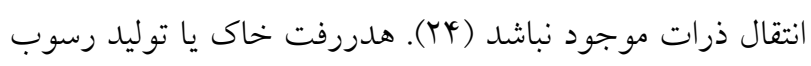

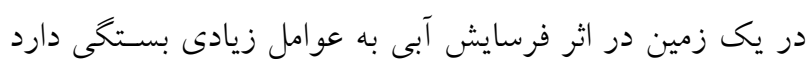

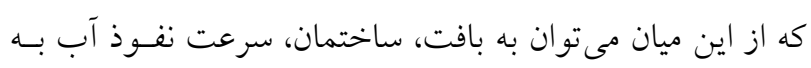

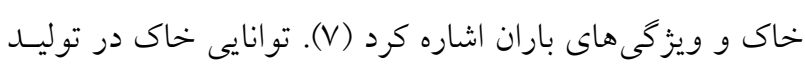

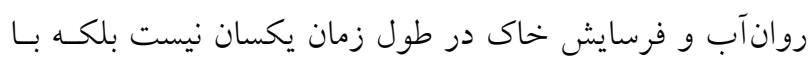

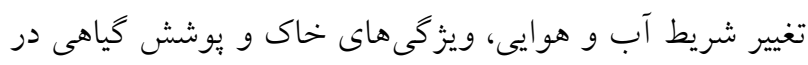

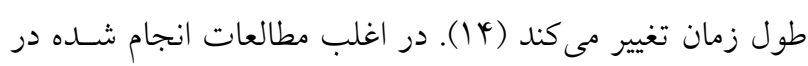

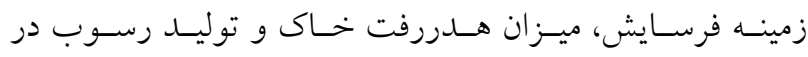

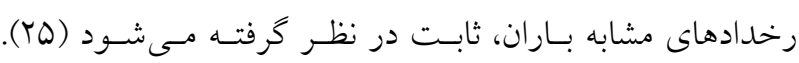

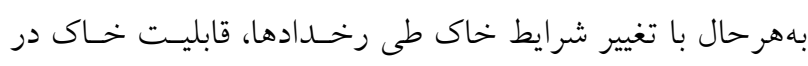
توليد رواناب و فرسايش يذيرى خاك دستخوش تغيير مى خـــد دد.

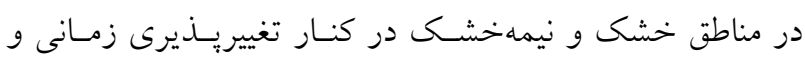
مكانى بارش، تغييـرات شـرايط سـطحى از جملـه خصوص وصسيات

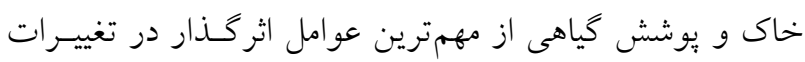

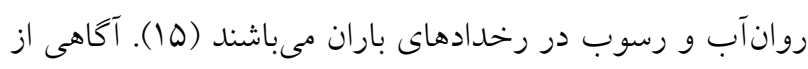

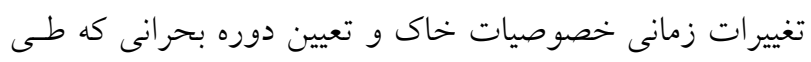
آن خاى حساس به فر آيندهاى فرسايش مى خــردد، بسـيار حسائز

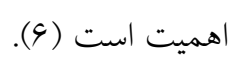

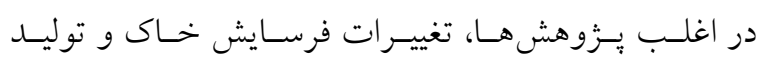

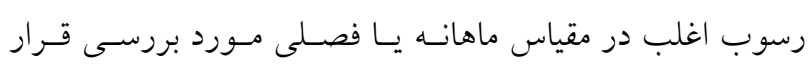

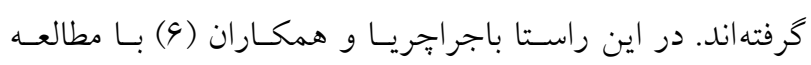
تغييرات فصلى فرسايش در ايالت اوهايو نشان دادند كـه ميـزان

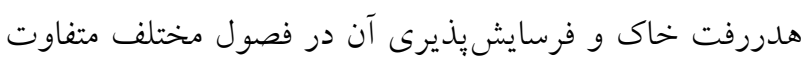

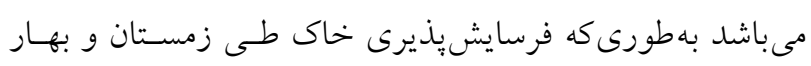

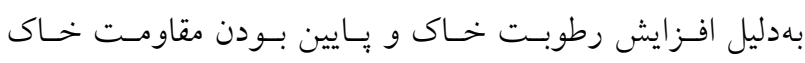

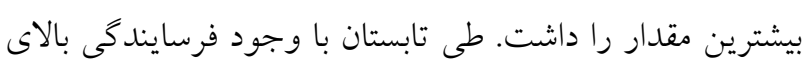

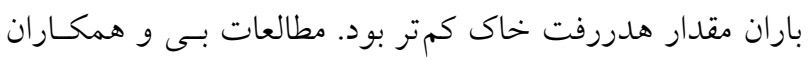




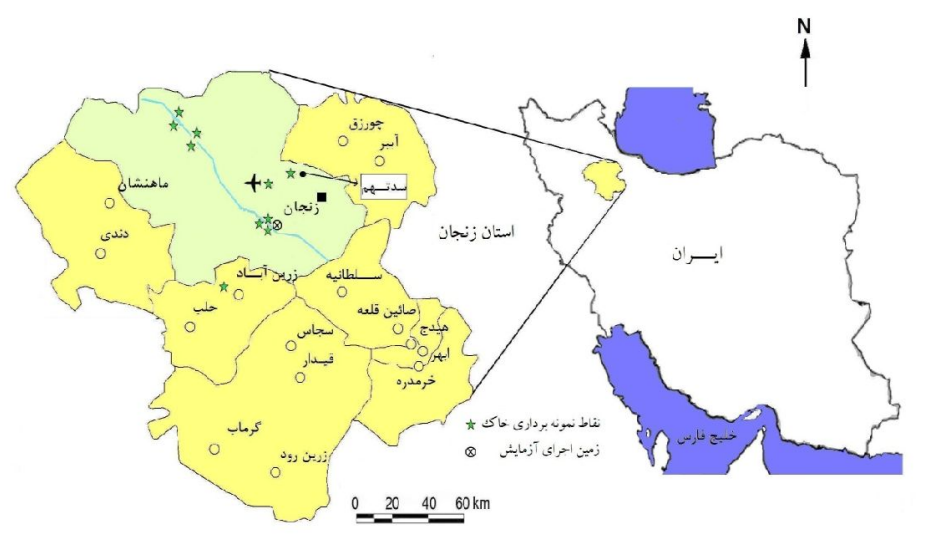

شكل 1. موقعيت جغرافيايى خاكهاى نمونهبردارى شده

\section{مواد و روشها} شناسايى و نمونهبردارى بافتهاى مختلف خاك و طرح آزمايش اين يزوهش در بخشى از خاكهاى استان زنجـان تحـت بـاران

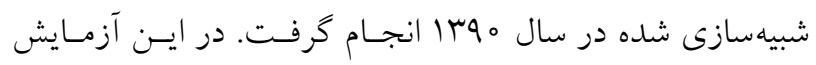

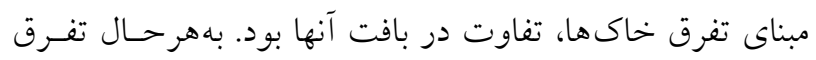
بافت خاك ممكن است منجر به تفاوت خـاكهـا از نظـر سـاير

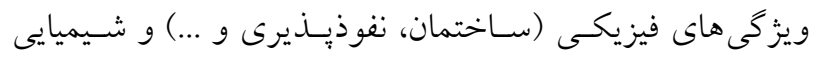

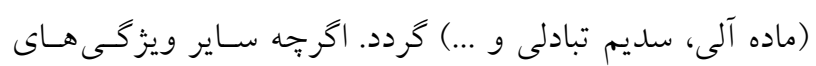

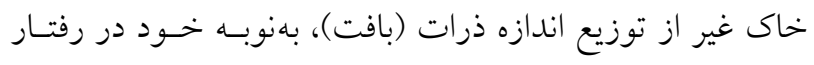

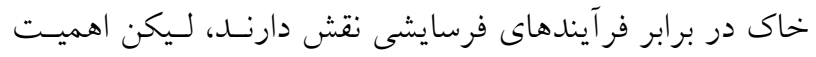

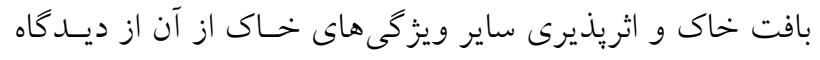

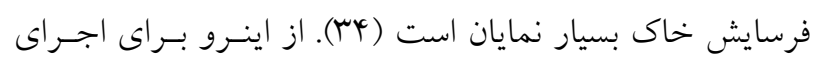

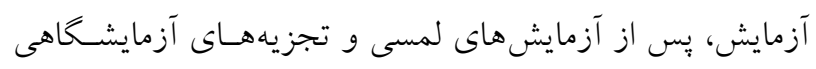

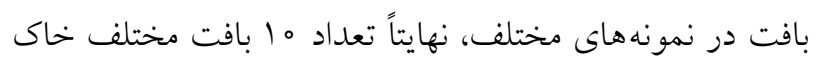

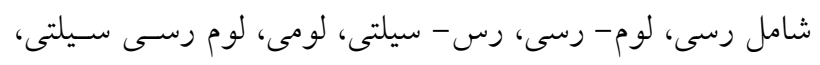

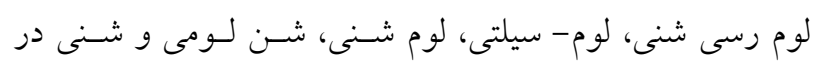

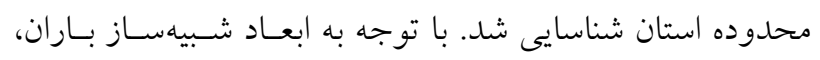

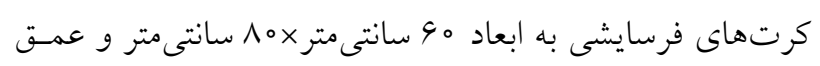

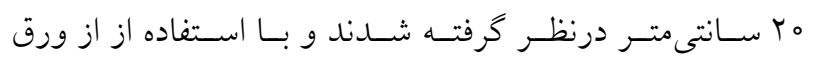

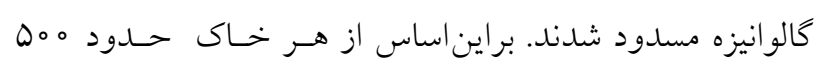

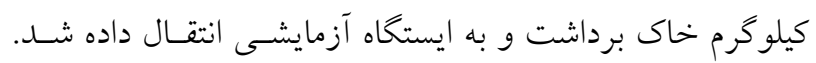

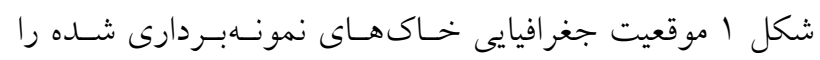

بارندگى عـاملى مهـم در توليـد روان آب و رسـوب بـوده و بـا

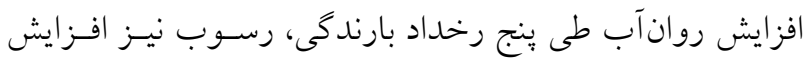

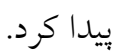
هر جندل در مورد تغييرات زمـانى فرسـايش خـاك تحـت

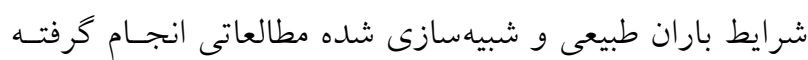

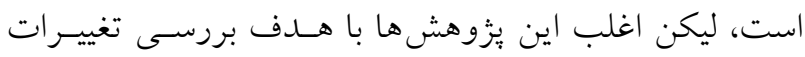

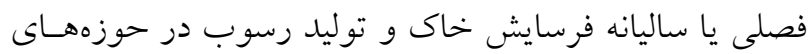

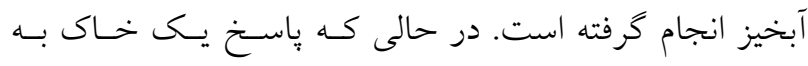

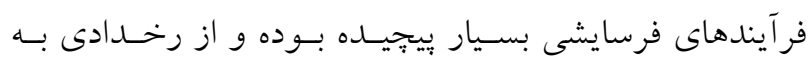

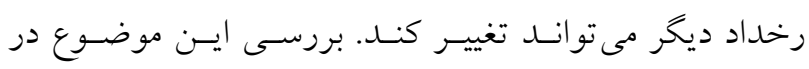
خاكهاى مختلف در يكى منطقه و تحت باران طبيعى بسئسيار

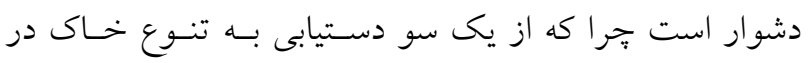
منطقهاى با بارندگى يكنواخت، دشوار بوده و از سـوى ديخـر

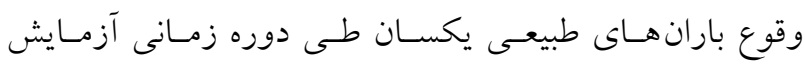

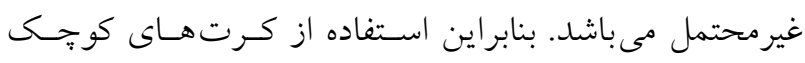

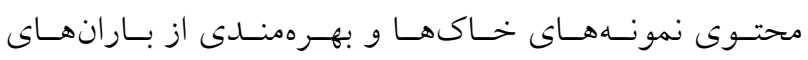

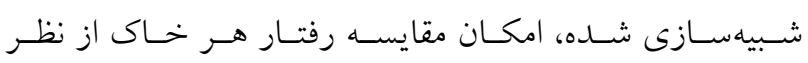

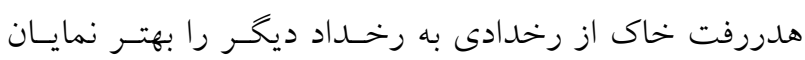

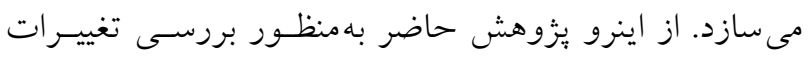

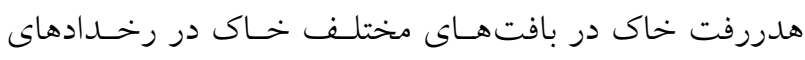
باران شبيهسازى شده انجام گرفت. 


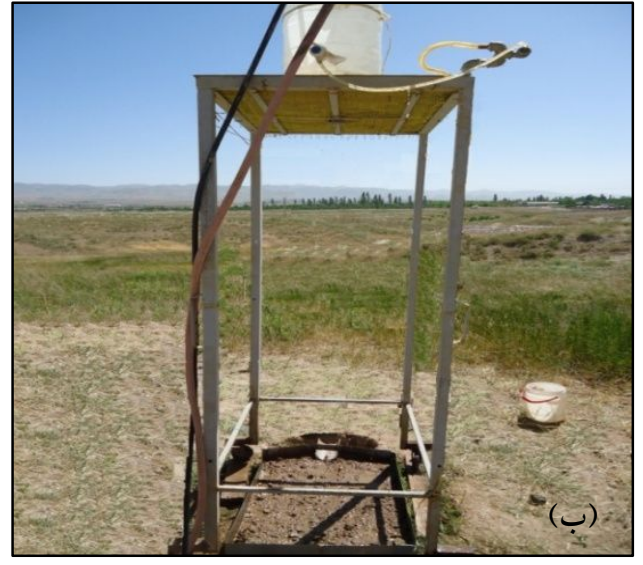

خاكهاى مختلف و ب) بارانساز مورد استفاده در آزمايش

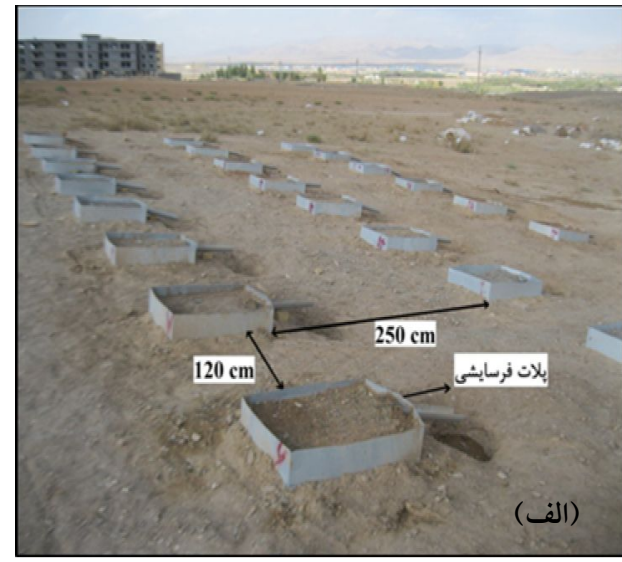

شكل r. الف) نمايى از كرتهاى فرسايشى محتوى
دستخاه مذكور داراى YVo نازل قطرهساز بود كه توانيايى توليـد

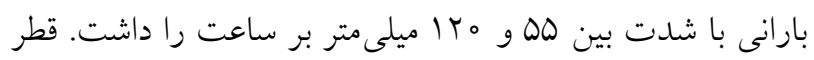

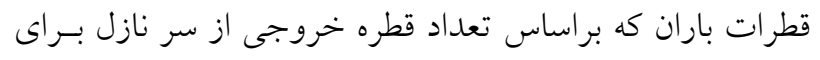

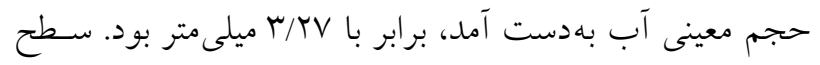

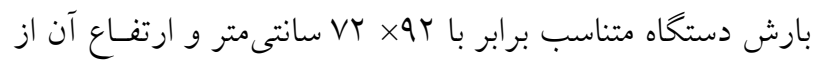

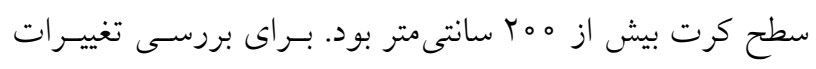

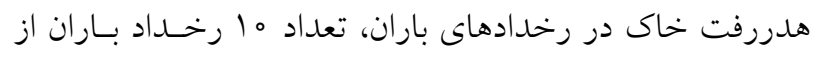

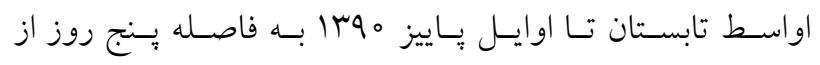

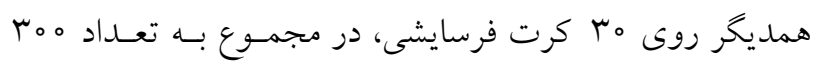

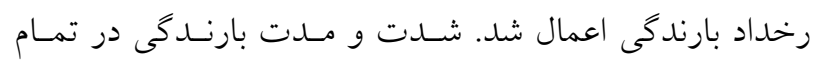

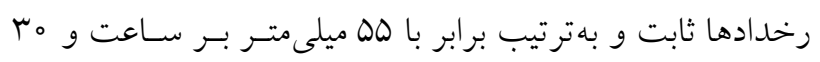

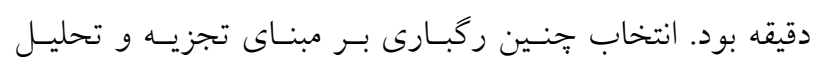

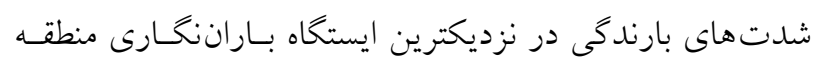

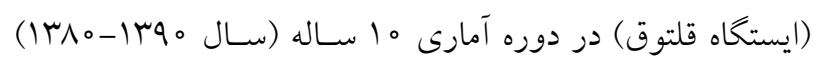

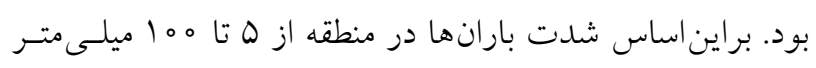

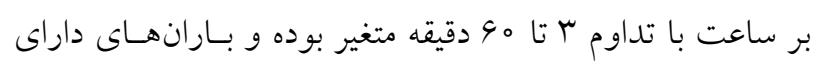

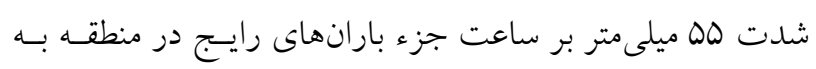

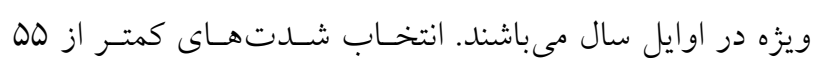

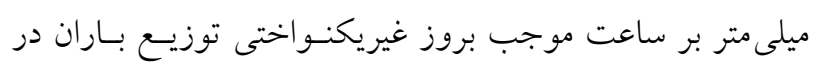

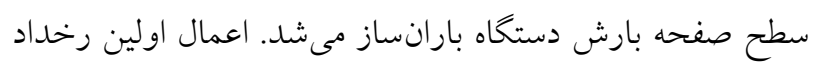

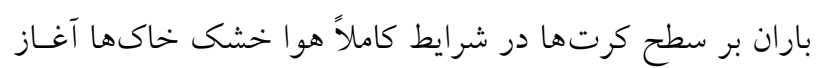

نشان مىدهد.

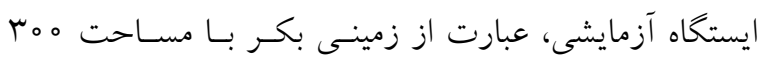

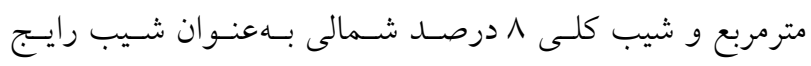

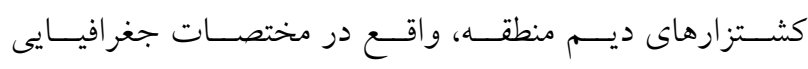
r

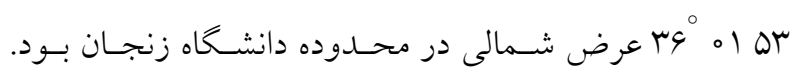

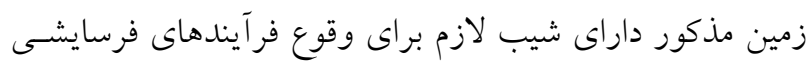

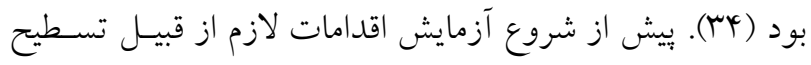

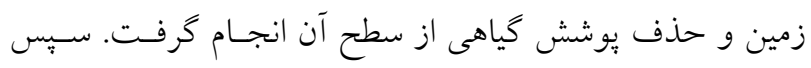

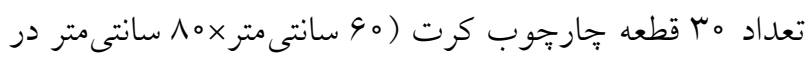

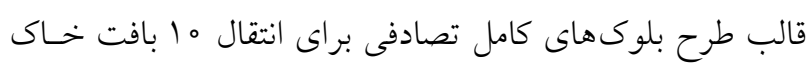

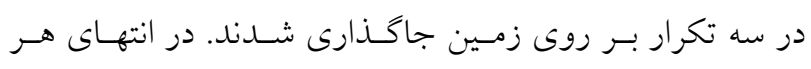

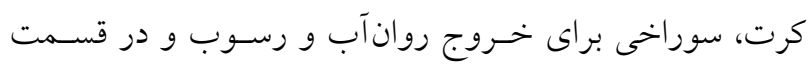

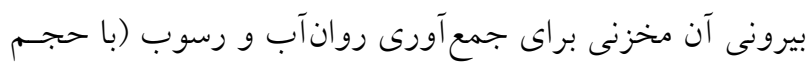

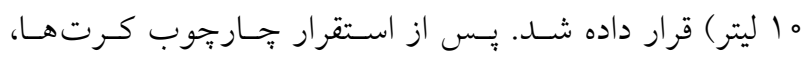

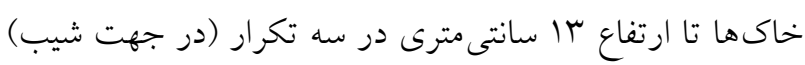

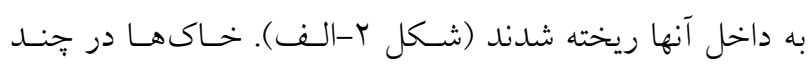

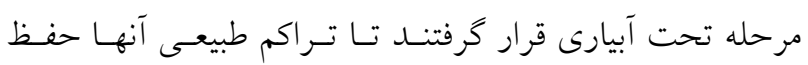
كردد.

اندازهيرى هدررفت خاك تحت رخدادهاى باران

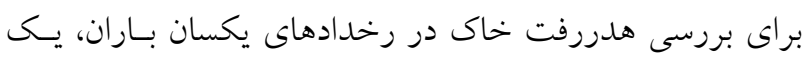

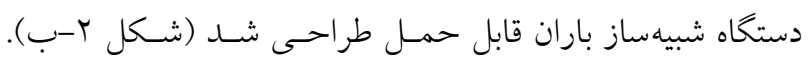


صحرا (r) و هدايت هيدروليكى اشباع بهروش بار ثابـت (بآ)

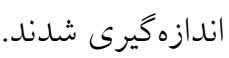

\section{تجزيه و تحليل دادهها}

يس از جمع آورى و ثبت دادهها در محسيط نــرمافـزارى Excel؛ براى تجزيه و تحليل آمارى از نرمافزار SPSS نسخه

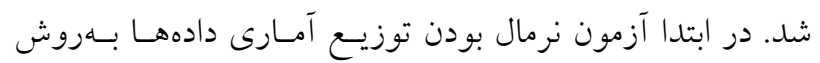
هيستو گرام و با تحليل جولكى و كشيدگى دادهها انجام گرفتـ. تفاوت رخدادهاى باران از نظر توليد روانآب و هدررفت خاك و رطوبت اوليه خاكها بهروش مقايسـه ميـانخين بـا اسـتفاده از

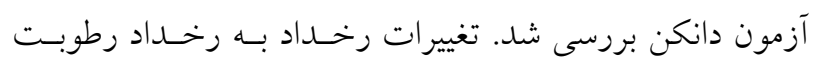

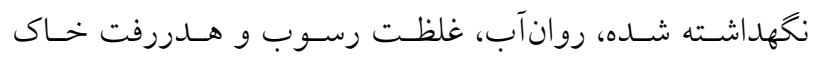
بهـور همزمان رسم و مورد بررسى قرار گرفت. همجينين بـراى تعيين رابطه بين هدررفت خاك طى رخدادها و عوامل مؤثر بــر آن از توابع مختلف (خطى، نمايى و ...) بهره گرفته شد.

\section{نتايج و بحث}

جدول ا نتايج برخى شاخصهاى آمارى ويزگىهاى فيزيكى و شيميايى خاك هاى منطقه مورد مطالعه در استان زنجان را نشـان مى دهد. همانطور كه ملاحظه مى شود خـاك منطقـه داراى مـواد

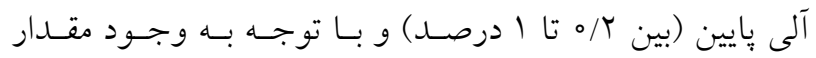

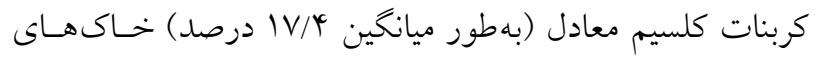

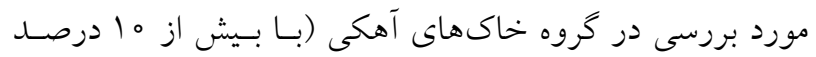

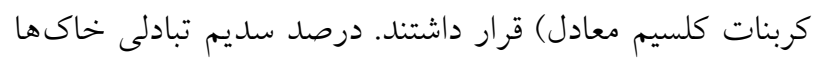

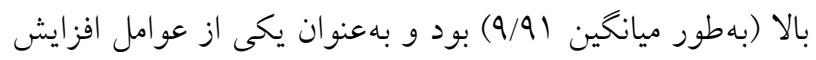

$$
\text { حساسيت خاكها به فرآيندهاى فرسايش آبى بود. }
$$

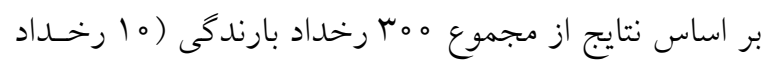

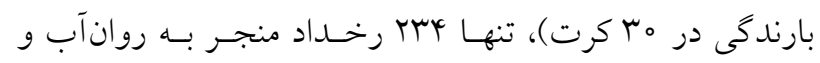

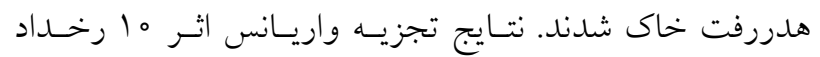

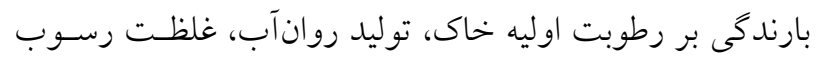
و هدررفت خاك (جدول r) نشان داد كه هر يك از متغيرهـاى لناى

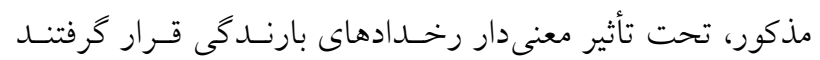

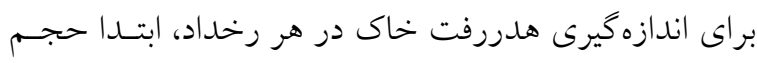

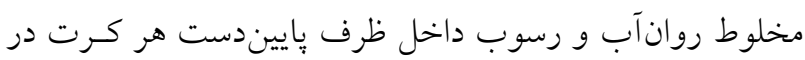

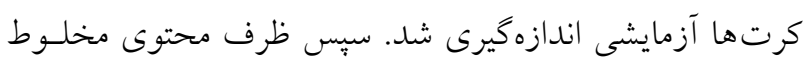

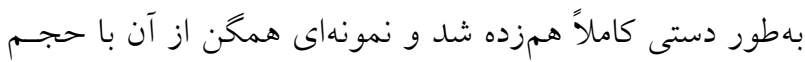

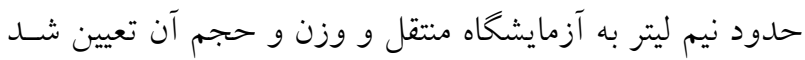

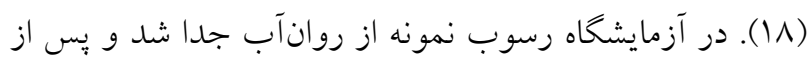

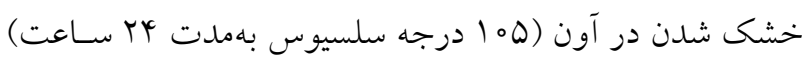

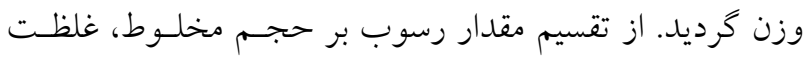

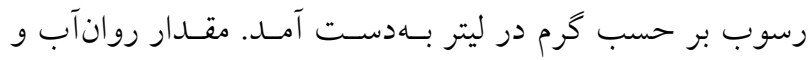
هدررفت خاك براساس غلظت رسوب و حجـم كـل مخلـوط

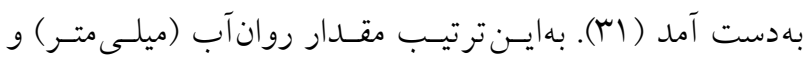
هدررفت خاك (كرم در مترمربع) براى هر كرت بهطور جداكانه

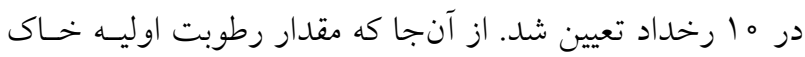

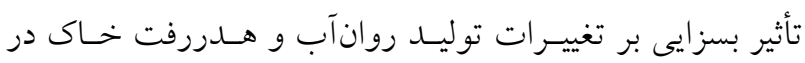

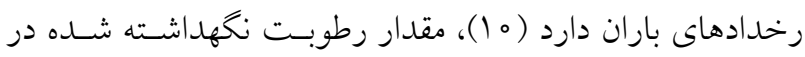

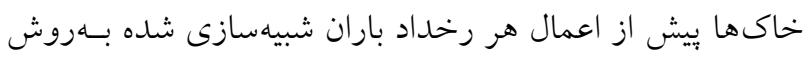

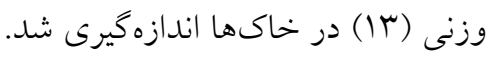

\section{تعيين ويزگگ هاى خاكها}

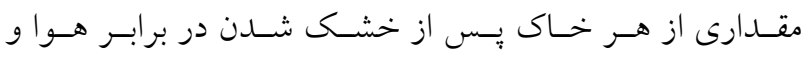

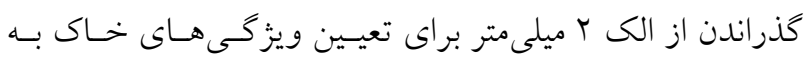

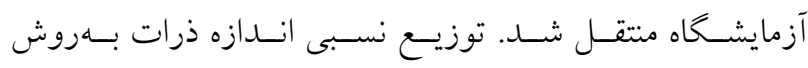

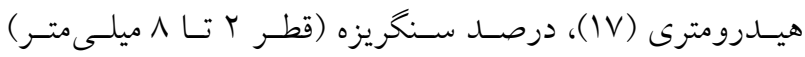
بهروش وزنى، جرم مخصوص حقيقى بـهروش بيكنسومتر (19)،

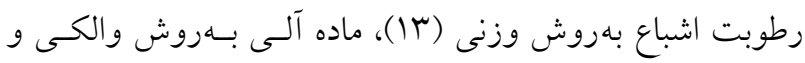

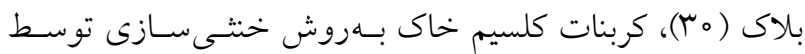

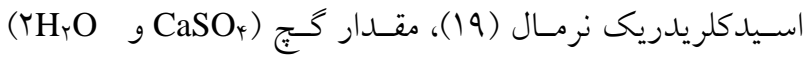

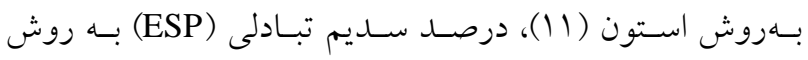

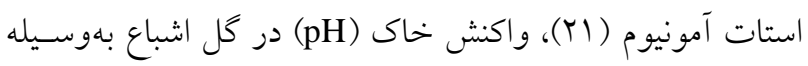

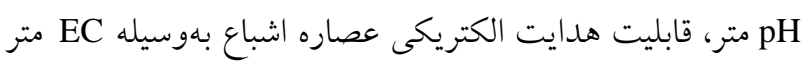

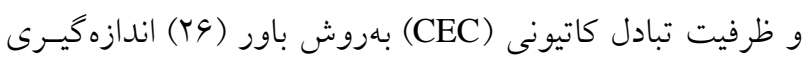

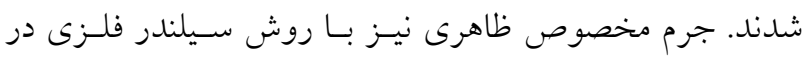


جدول ا. برخى مشخصات آمارى ويزگى هاى فيزيكى و شيميايى خاكهاى مورد مطالعه

\begin{tabular}{|c|c|c|c|c|}
\hline انحراف معيار & ميانكين & بيشترين & 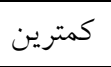 & 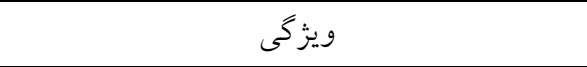 \\
\hline T/VQ & $4 \circ / 9 V$ & $\Lambda V / Q 1$ & $\Lambda / \mu r$ & شن ( درصد ) \\
\hline IN/IV & $r q / r)$ & $9 T / 9 V$ & $r / \Delta \wedge$ & سيلت (درصد) \\
\hline $19 / 14$ & $r \circ / 10$ & $9 N / 94$ & $N / 91$ & رس (درصد) \\
\hline$\circ / \mathrm{V}$ & $1 / 4 \pi$ & $1 / 90$ & $1 / 0 r$ & جرم مخصوص ظاهرى (كرم بر سانتىمتر مكعب) \\
\hline $19 / \pi 9$ & $\uparrow 9 / 4 \Lambda$ & $V T / / T$ & rQ/9T & رطوبت اشباع (درصد) \\
\hline$r / 94$ & $r / N$ & $9 / 09$ & $1 / 19$ & هدايت هيدروليكى اشباع (سانتىمتر بر ساعت) \\
\hline$\circ / r_{0}$ & $\mathrm{~V} / \mathrm{N}_{\Lambda}$ & $V / V I$ & $V / 10$ & واكنش خاى \\
\hline.$/ 49$ & $1 / \Delta \Delta$ & $r / \Delta r$ &.$/ \Delta F$ & قابليت هدايت الكتريكى (دسىزيمنس بر متر) \\
\hline$\varphi / \circ V$ & $9 / 91$ & $19 / 40$ & r & درصد سديم تبادلى \\
\hline$\circ / \Delta 9$ & $0 / 91$ & $1 / 11$ &.$/ 19$ & ماده آلى (درصد) \\
\hline$\varphi / l V$ & $1 \mathrm{~V} / \mathrm{rq}_{\mathrm{G}}$ & $r \Delta / \wedge V$ & IT/AV & كربنات كلسيم معادل (درصد) \\
\hline
\end{tabular}

جدول r. تجزيه واريانس اثر رخدادهاى باران بر رطوبت نگهداشته شده، توليد روانآب، غلظت رسوب و هدررفت خاك

\begin{tabular}{|c|c|c|c|c|}
\hline سطح معنى دارى & $\mathrm{F}$ & ميانخين مربعات & درجه آزادى & منبع تغيير \\
\hline$\circ / 0 \circ 0$ & DV/M & IV/OT & 9 & رطوبت اوليه خاك \\
\hline $0 / 000$ & $\Delta \circ / V \Delta$ & $\mu r / \Delta D$ & 9 & توليد روانآب \\
\hline$\circ / 0 \circ 0$ & $I V / O r$ & $|4| / 09$ & 9 & غلظت رسوب \\
\hline$\circ / 000$ & $19 / 01$ & $|O M Y V Y / \Lambda|$ & 9 & هدررفت خاى \\
\hline
\end{tabular}

افزايش رطوبت نخهماشته شده در خاك در طلى ايسن رخــادها كمتر از رخدادهاى ييشين بود. در واقع رطوبت نخهـدارىشــهـ

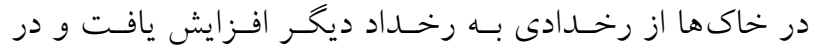
نهايت در رخحادهاى بايانى مقدار رطوبـت نخهـدارى شــده در

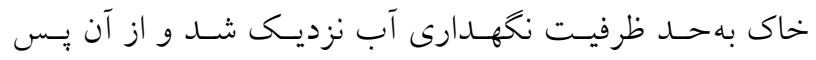

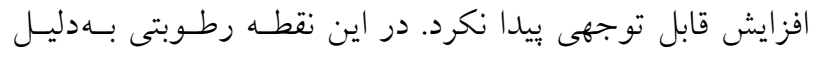

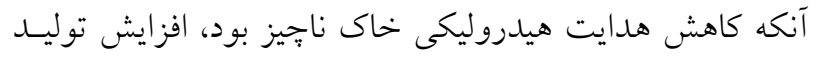
روانب نيز روندى تدريجى نشان داد.

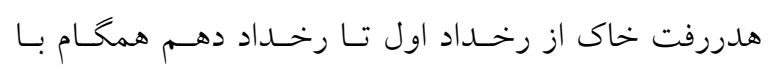

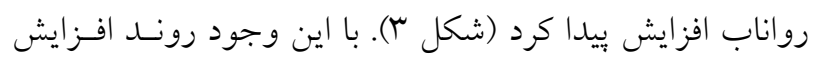
هدررفت خاك از رخدادى به رخهـداد ديخـــ از الكـويى تقريبـاً

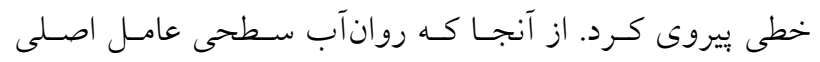

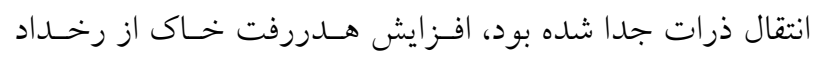

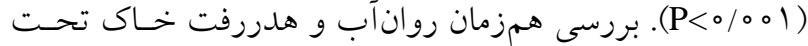

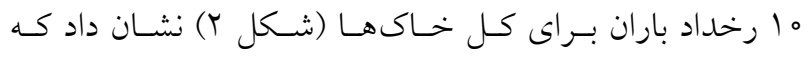

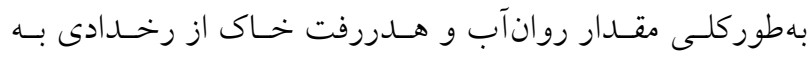
رخداد ديخر افـزايش بيــا كـرد بـهــورىكـهـ بيشـترين مقــدار

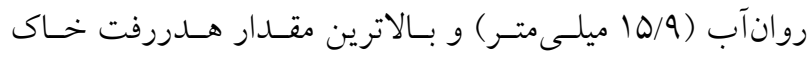

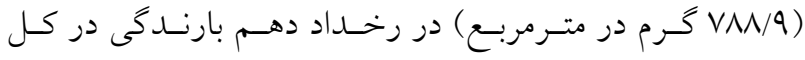
خاكها مشاهده شد. توليد روان آب از رخداد اول تا رخداد هفتم ابتدا با رونسدى سلد

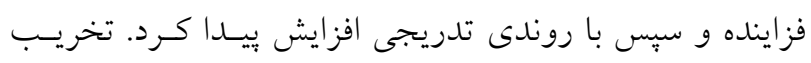

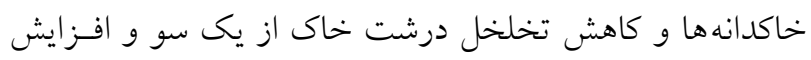

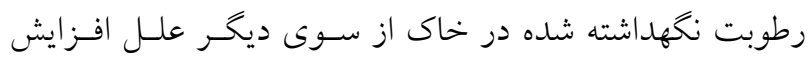

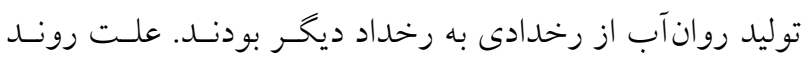

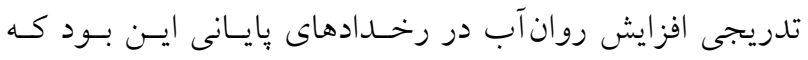




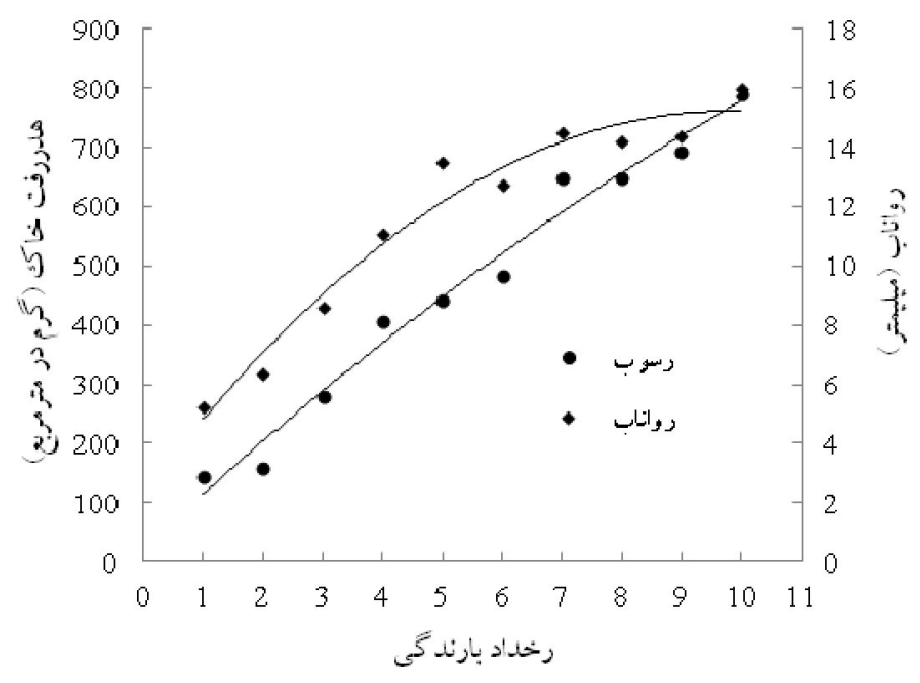

شكل r. تغييرات هدررفت خاك و توليد روانآب در خاكها تحت رخدادهاى يكسان باران

نيز بيان كردند كه فراوانى رخدادهاى باران مى تواند نقش مهمى

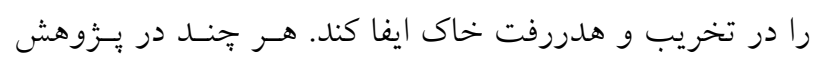

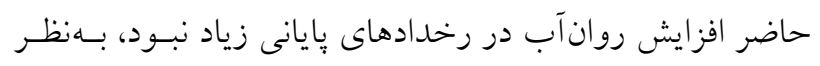

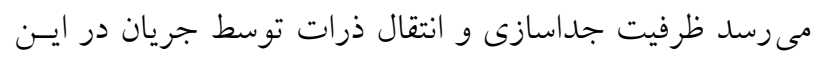

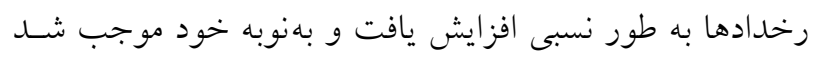

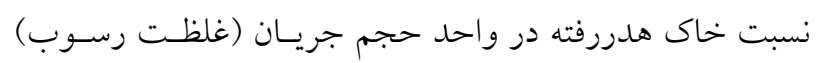

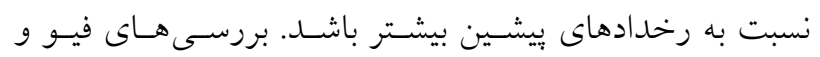

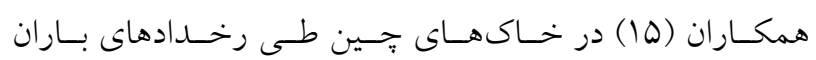

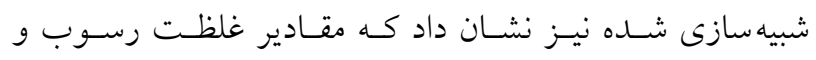

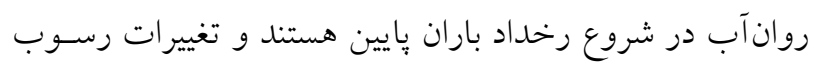

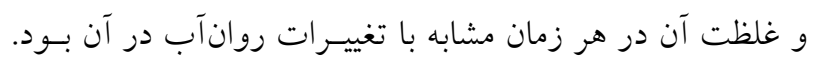

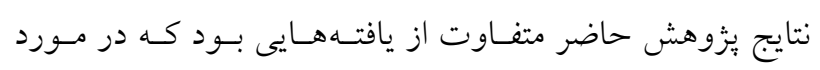

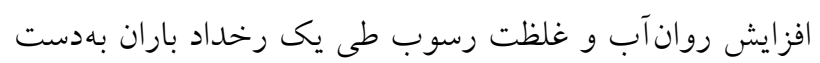

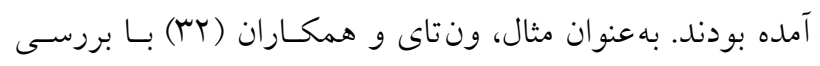

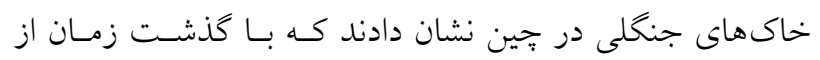

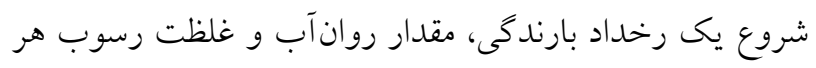

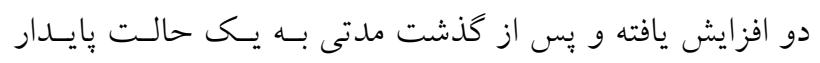

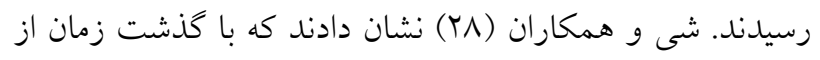

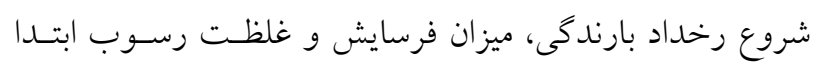

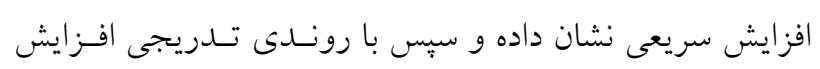

اول تا رخداد هفتم بـهدليـل افـزايش توليـــ روان آب طـى ايسن رخدادها بود. در رخدادهاى اول و دوم بهدليـل رطوبـت بسـيار

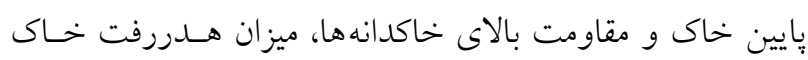

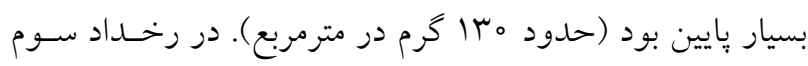

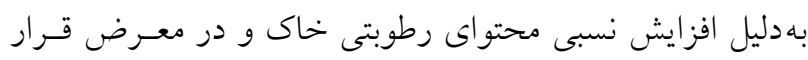

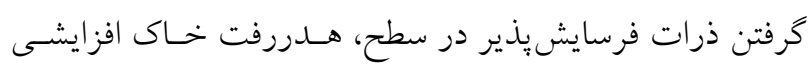

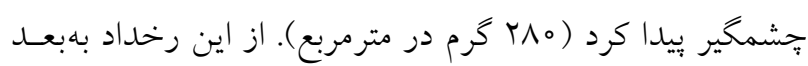

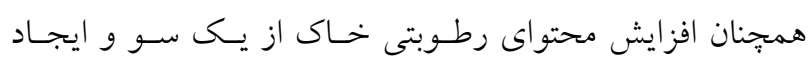

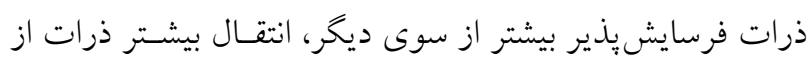

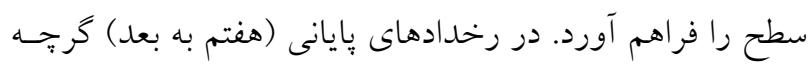

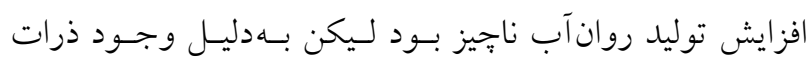

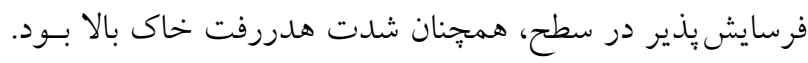

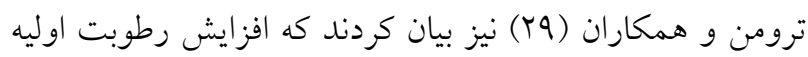
خاك ناشى از بارشهاى قبلى باعث كاهش بايدارى خاكدانههـا

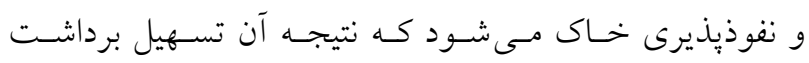

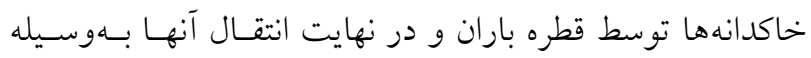
جريانهاى سطحى است. يافتهاى حميدى نهرانسى و همكـاران

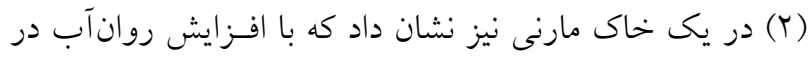

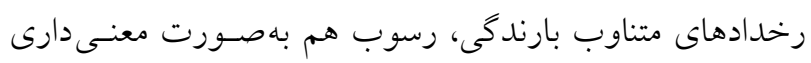

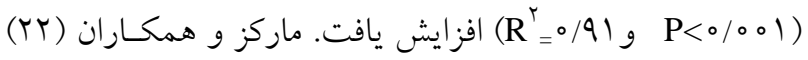




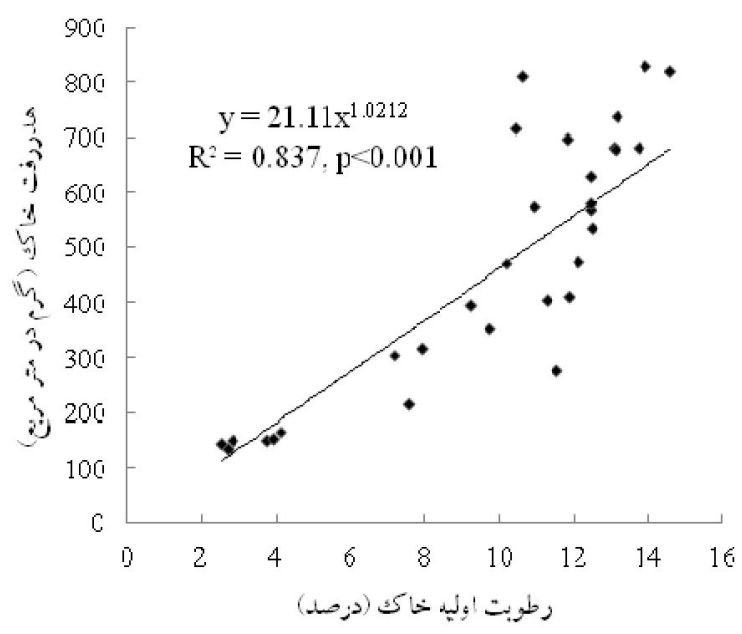

شكل F. رابطه بين هدررفت خاك و رطوبت اوليه در خاكها تحت رخدادهاى بارندگى

اصلى تشديد هدررفت خاك از رخدادى به رخداد ديخــ دانسـت.

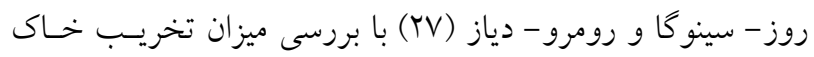

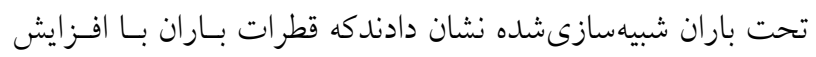

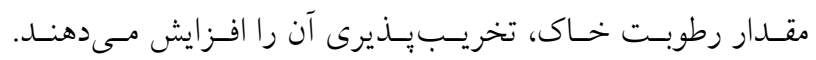

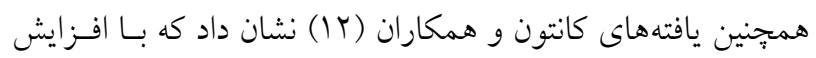

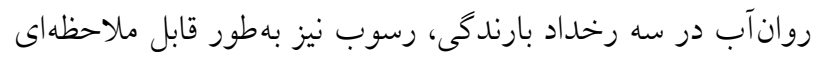

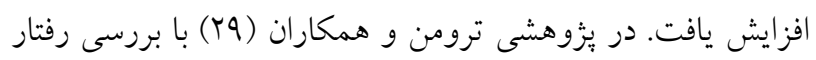

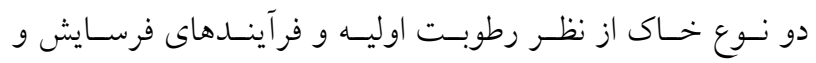

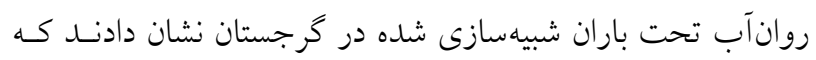

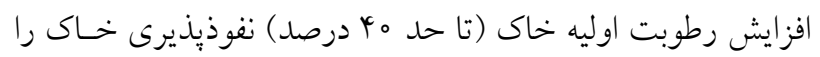

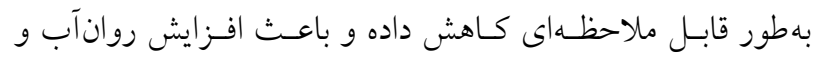

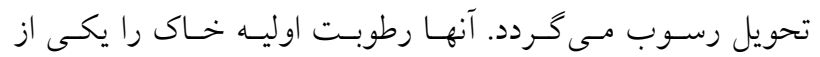

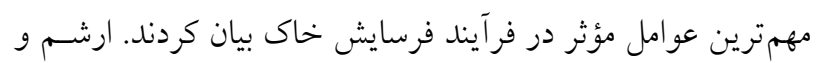

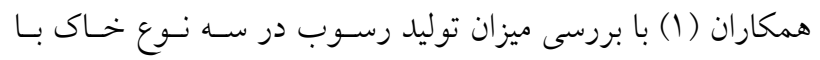

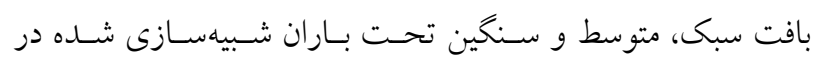

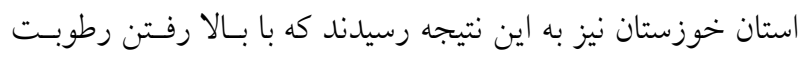

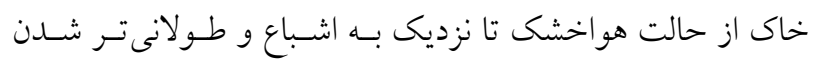

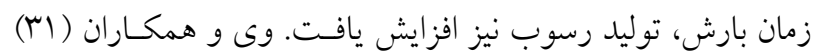

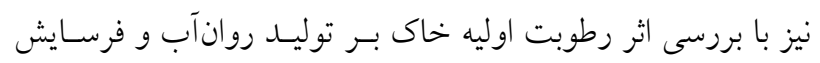

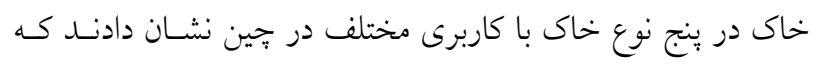

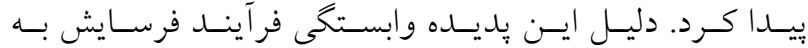
محدوديت در سيستم انتقال رسوب و جداسازى ذرات بهوسيله قطرات باران بود. زين و همكاران (Yo) نيز با بررسى تغييـرات

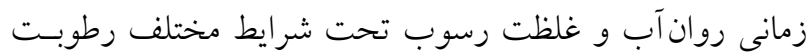

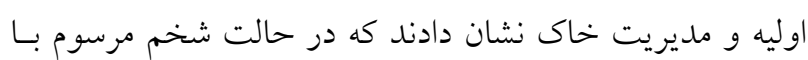

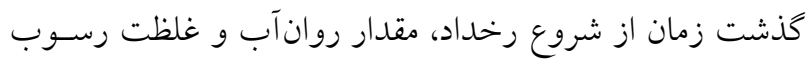

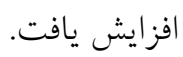

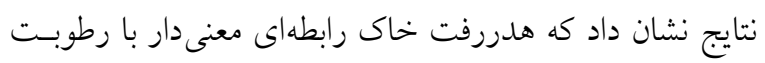

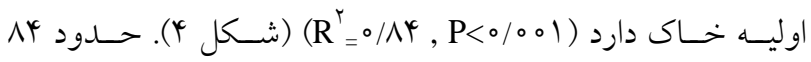
درصد تغييرات هدررفت خاك طى رخدادهاى بـاران در خـاكهـا

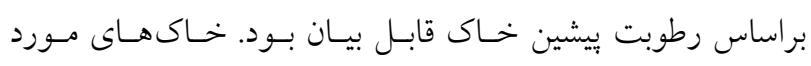

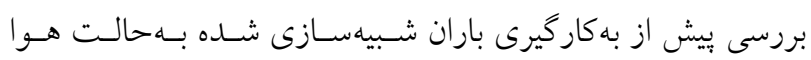

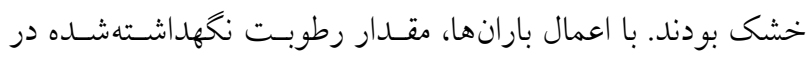

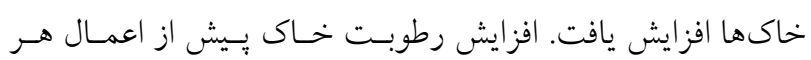
باران موجب شد كه مكش خاك به سرعت كاهش يابد و در نتيجه

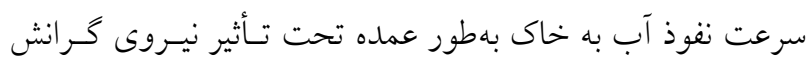

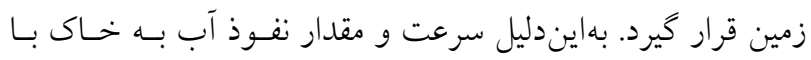

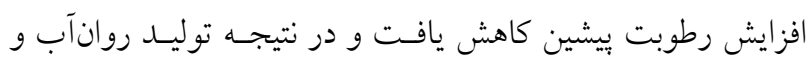

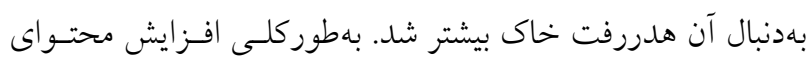

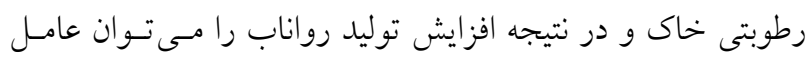




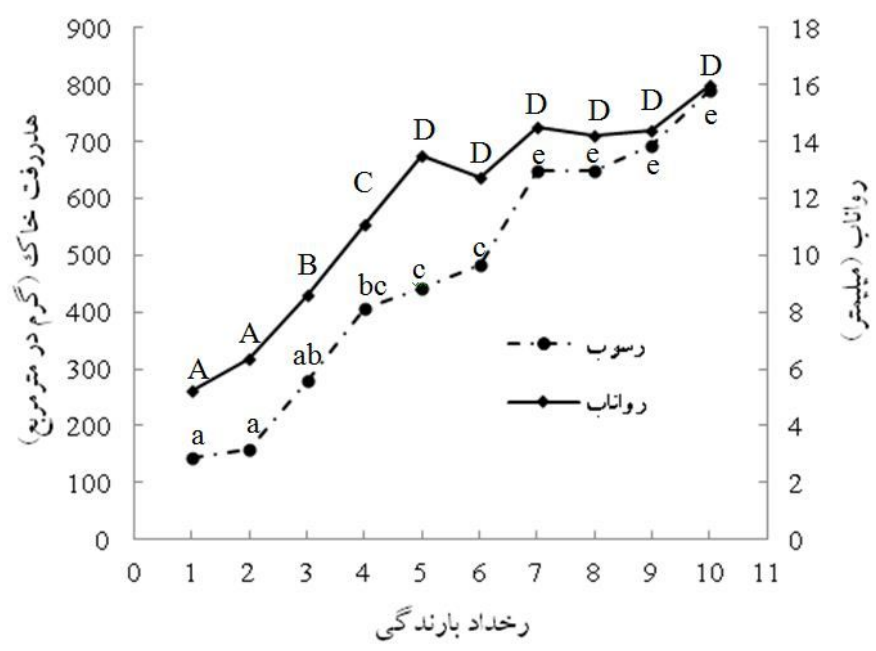

شكل ه. مقايسه آمارى ميزان تأثير رخدادهاى باران بر رطوبت نكهداشته شده و هدررفت خاك در خاكها (حروف انخليسى كوجّى و بزرگ، نشاندهنده گروههاى آمارى رخدادهاى باران بهترتيب از نظر هدررفت خاك و رواناب مىباشند.)

مىرود نسبت تخريب خاكدانهها در رخدادهاى آغازين بيشتر از

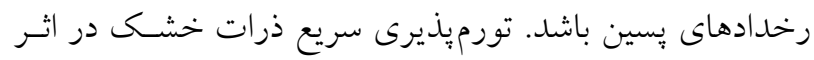

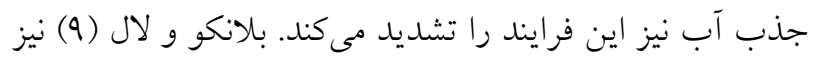

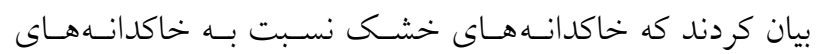
مرطوب، آب باران را سريعتر جذب كرده و در نتيجه با انبسـاط

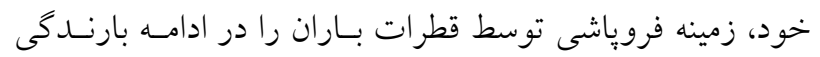

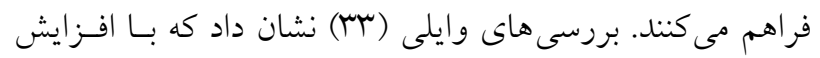
تعدادو تداوم رخدادهاى باران، ساختمان خاك بيشـتر تخريـب فئس شده و در اثر افزايش رطوبت اوليه خاك طى رخدادهاى بـاران،

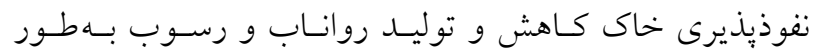

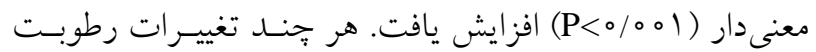

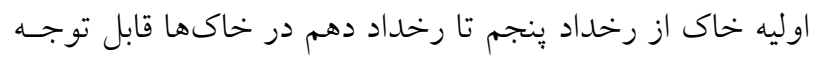

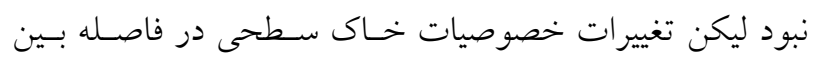

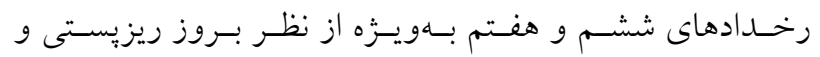

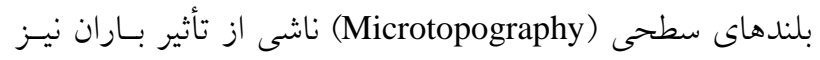

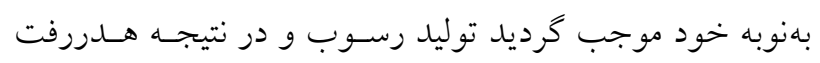

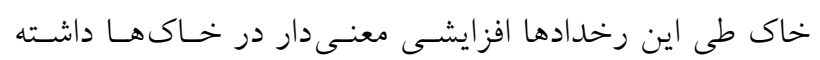

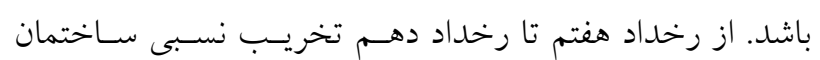

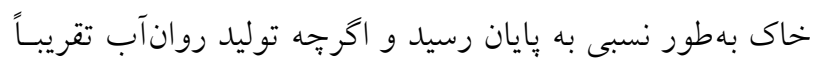

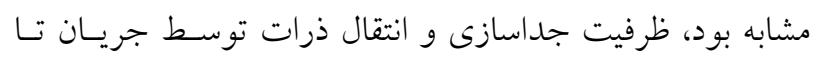

در رخدادهاى مشابه مقادير روان آب و رسوب متفـاوت اسـت. ايـن

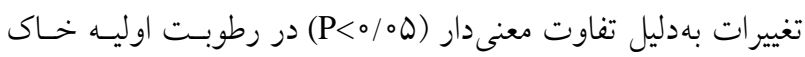
بين رخدادهاى باران بود.

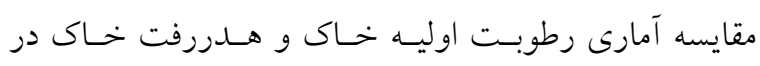

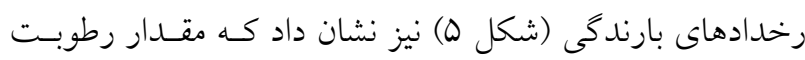

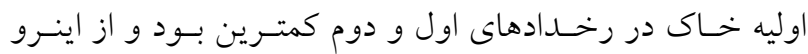

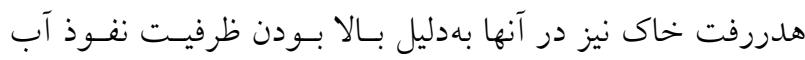

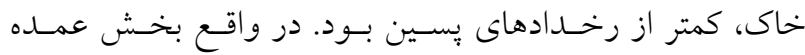
بارندگى طى اين رخدادها به خاكها جذب شد و بهدليل بـايين

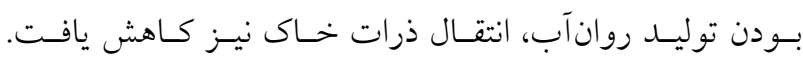

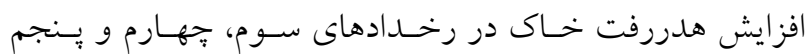
نسبت به همديخر تا اندازهاى قابل توجه بود. هر جنــد تغييـرات زمانى خصوصيات خاك سطحى از جمله ساختمان خاك، ميزان فرسايش خاى را طى اين رخدادها تحت تـأثير قـرار داد (م) (1)،

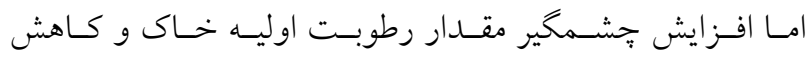

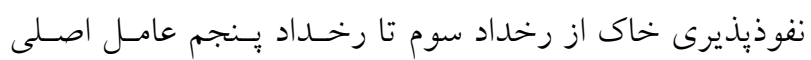

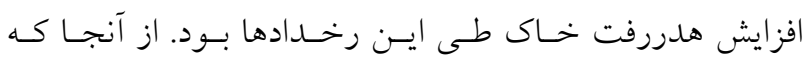

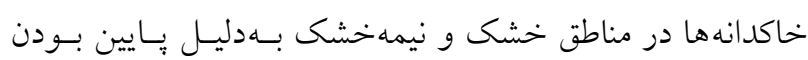

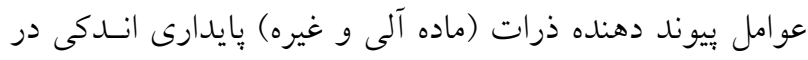
برابر نيروهاى خارجى از جمله ضربه قطرات باران دارند، تصور 


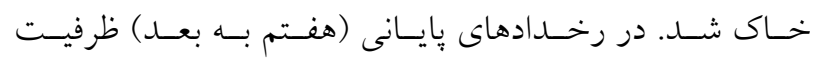

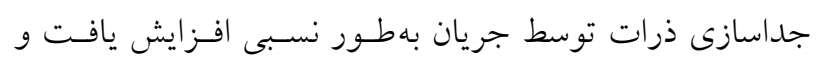

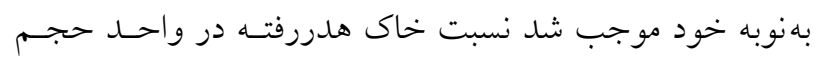
جريان (غلظت رسوب) نسبت به رخدادهاى بيشين بيشتر باشد.

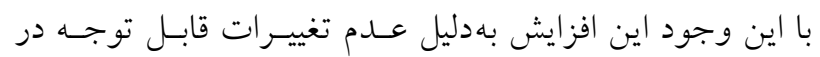

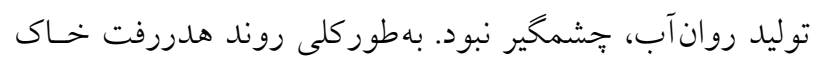

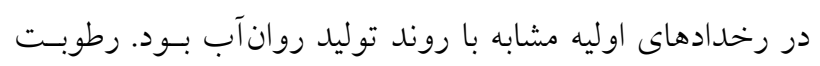

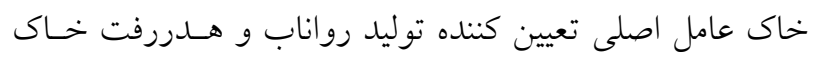

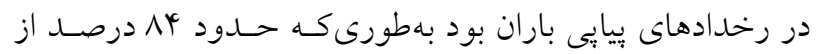

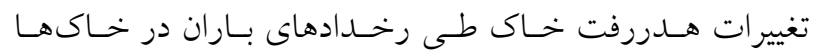
براساس رطوبت بيشين خاك قابل بيـان بـود. ايسن نتـايج نشـان مى دهد كه در خاك هاى با ساختمان نايايــار مانــــ بسـيارى از

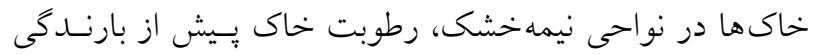

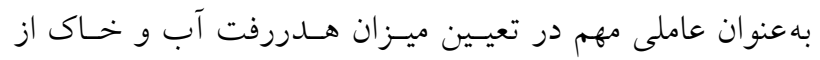

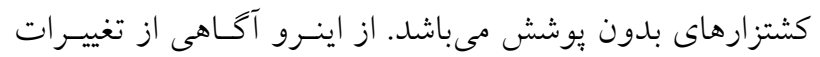
رطوبت خاى در يك منطقه مى تواند در بيشبينى توليد روانـاب إنساب در رخدادهاى مختلف باران طى سال مؤثر واقع كردد.
اندازهاى بالا بــود. بــا ايـنـ وجــود تفـــاوت قابـل ملاحظـهـاى در هدررفت خاك در اين رخدادها مشاهده نخرديد.

\section{نتيجه گيرى}

نتايج نشان داد كه مقدار آب نخهداشته شده در خاكهـا، توليـــ

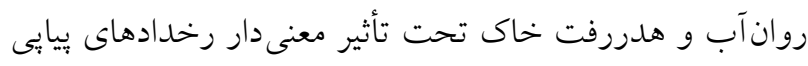

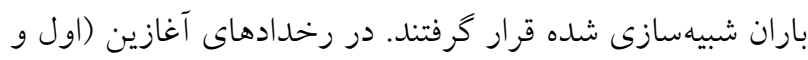

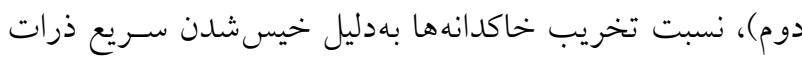

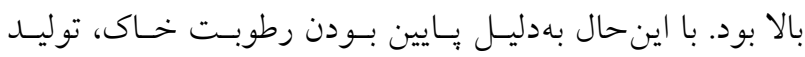

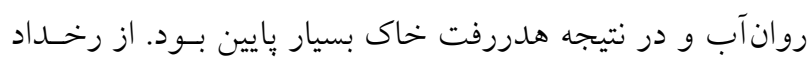
سوم تا رخداد ينجم همخام با افـزايش رطوبـت بيشسين خـاك، توليد رواناب و در نتيجه هدررفت خاك بهشدت افزايش يافت.

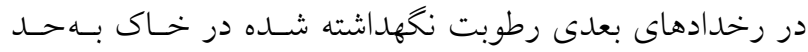

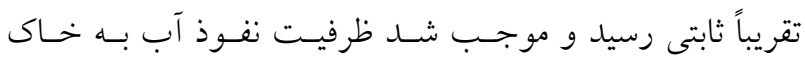
كاهش جشمحيرى بيدا نكند. از اينرو افزايش قابـل ملاحظـهاى

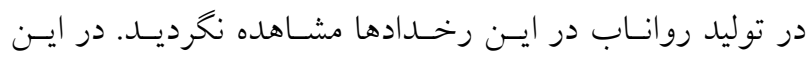
رخدادها تخريب ساختمان خاك همجنان بـهـور نسـبى ادامـهـ

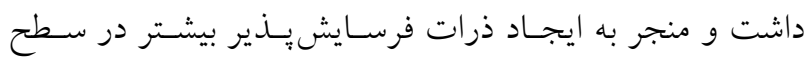

\section{منابع مورد استفاده}

ا. ارشم، ع.، ع. م. آخوندعلى و ع. بهنيا. MM ا. بررسى اثر رطوبتهاى قبلى خاك بر مقـادير روان آب و رسـوب بـا استفاده از بـاران

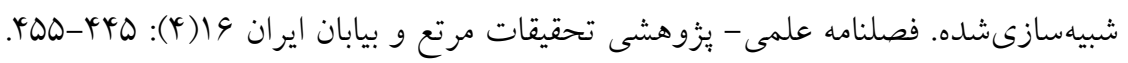

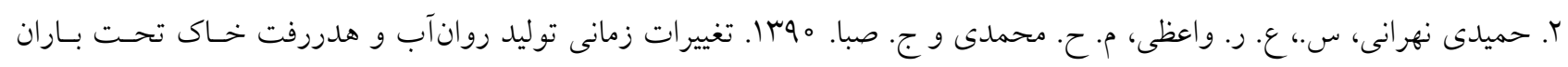

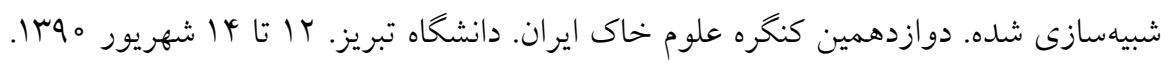

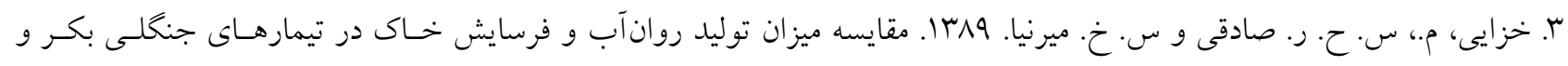

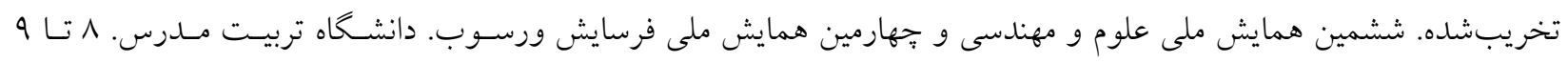

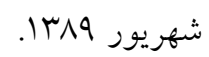

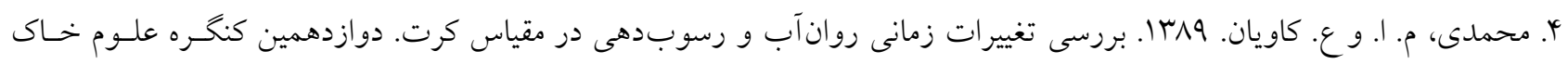

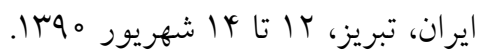

5. Baihua, F., T. H. Lachlan, C. E. Newham and S. Ramos. 2010. A review of surface erosion and sediment delivery models for unsealed roads. Environ. Model. Softw. 25: 1-14.

6. Bajracharya, R. M., R. Lal and G. F. Hall. 1998. Temporal variation in properties of an uncropped, ploughed Miamian soil in relation to seasonal erodibility. J. Hydrolo. Process. 12: 1021-1030.

7. Bhattacharyya, R., M. A. Fullen, K. Davies and C. A. Booth. 2010. Use of palm-mat geotextiles for rain splash 
erosion control. Geomorphology. 119: 52-61.

8. Bi, N., Z. Yang, H. Wang, D. Fan, X. Sun and K. Lei. 2011. Seasonal variation of suspended-sediment transport through the southern Bohai Strait. Estuarine, Coastal Shelf Sci. 93(3): 239-247.

9. Blanco, H. and R. Lal. 2008. Principles of Soil Conservation and Management. Springer Science, pp: 42-43.

10. Bryan, R. B. 2000. Soil erodibility and processes of water erosion on hillslope. Geomorphology. 32: 385-415.

11. Burt, R. 2009. Soil survey field and laboratory methods manual. Soil Survey Investigations Report No. 51. Lincoln, Nebraska.

12. Canton, Y., A. Sole-Benet, C. Asensio, S. Chamizo and J. Puigdefabregas. 2009. Aggregate stability in range sandy loam soils relationship with runoff and erosion. Catena. 77: 192-199.

13. Carter, M. R. and E. G. Gregorich. 2008. Soil sampling and methods of analysis, second edition. Canadian Society of Soil Science Publisher. ISBN10: 0-8493-3586-8.

14. Chang, H. and I. L. Won Jung. 2010. Spatial and temporal changes in runoff caused by climate change in a complex large river basin in Oregon. J. Hydrol. 388: 186-207.

15. Fu, B., Y. Wang, P. Xu and D. Wang. 2009. Changes in overland flow and sediment during simulated rainfall events on cropland in hilly areas of the Sichuan Basin, China. Progress Natural Sci. 19: 1613-1618.

16. Gao, P. and M. Josefson. 2012. Event-based suspended sediment dynamics in a central New York watershed. Geomorphology 139-140: 425-437.

17. Gee, G. W. and J. W. Bauder. 1986. Particle size analysis. PP. 383-411. In: Klute, A. (Ed.), Methods of soil analysis, Part 1, $2^{\text {nd }}$ ed. Agronomy Monograph, Vol. 9. American Society of Agronomy, Madison, Wisconsin.

18. Girmay, G., B. R. Sing, J. Nyssen, and T. Borrosen. 2009. Runoff and sediment associated nutrient losses under different land uses in Tigray, Northern Ethiopia. J. Hydrol. 376: 70-80.

19. Hazelton, P. and B. Murphy. 2007. Interpreting soil test results. CSIRO publishing, Melbourne, p. 169.

20. Jin, K., W. M. Cornelis, D. Gabriels, W. Schiettecatte, S. De Neve, J. Lu, T. Buysse, H. Wu, D. Cai, C. Dianxiong, J. Jin and R. Harmann. 2008. Soil management effects on runoff and soil loss from field rainfall simulation. Catena. 75: 191-199.

21. Lujan, L. d. 2003. Soil physical properties affecting soil erosion in Tropical soils. Facultad de Agronomia, Instituto de Edafologia, Universidad Central de Venezuela, Maracay, Venezuela 232-243.

22. Marques, M. J., R. Bienes, L. Jimenez and R. Perez-Rodriguez. 2007. Effect of vegetal cover on runoff and soil erosion under light intensity events. Rainfall simulation over USLE plots. Science Total Environ. 378: 161-165.

23. McKenzie, N. J., T. W. Green and D. W. Jacquier. 2002. Laboratory measurement of hydraulic conductivity. PP: 150-162. In: McKenzie, N. J., K. L. Coughlan, H. P. Cresswell. (Eds.), Capter 10. Soil Physical Measurement and Interpretation for Land Evaluation. CSIRO Publishing, Melbourne.

24. Morgan, R. P. C. 2005. Soil erosion and conservation. PP: 13-60. $3^{\text {rd }}$ ed. Blackwell Publishing, Malden.

25. Rejman, J., R. Brodoweski and I. Iglik. 2008. Annual variations of soil Erodibility of silt loam developed from loess based on 10-years runoff plot studies. J. Annals Warsaw University of Life Sci. SGGW Land Reclam. 39: 77-83.

26. Rhoades, J. D. 1982. Cation exchange capacity, Methods of soil analysis, Agronomy, Noumber. 9, Chemical and mineralogical properties, Society. Agronomy, Madison. WI, USA, pp:149-157.

27. Ruiz-Sinoga, J. D. and A. Romero-Diaz. 2010. Soil degradation factors along a Mediterranean pluviometric gradient in southern spain. Geomorphology 118(3-4): 359-368.

28. Shi, Z. H., N. F. Fang, F. Z. Wu, L. Wang, B. J. Yue and G. L. Wu. 2012. Soil erosion processes and sediment sorting associated with transport mechanisms on steep slopes. J. Hydroly. 454-455: 123-130.

29. Truman, C. C., T. L. Potter, R. C. Nuti, D. H. Franklin and D. D. Bosch. 2011. Antecedent water content effects on runoff and sediment yields from two coastal plain ultisols. Agri. Water Manage. 98: 1189-1196

30. Walkly, A. and I. A. Black. 1934. An examination of digestion methods for determining soil organic matter and a proposed modification of the chromic and titration. Soil Sci. Soc. . Am. J. 37: 29-38.

31. Wei, L., B. Zhang and M. Wang. 2007. Effects of antecedent soil moisture on runoff and soil erosion in alley cropping systems. Agri. Water Manage 94: 54-62.

32. Wen-Tai, Zh., Y. Dong-Sheng, S. Xue-Zheng, T. Man-Zhi and L. Liu-Song. 2010. Variation of sediment concentration and its drivers under different soil management systems. Pedospher. 20(5): 578-585.

33. Willy, K. N. 2011. The role of the aggregate size in soil resistance and decrease erosion. Soil Sci. Soc. Am. J. 10(15): 111-120.

34. Wischmeier, W. H. and D. D. Smith. 1978. Predicting rainfall erosion losses. PP. 1-62. U.S. Dep. Agr., Sci. Edu. Admin., Agr. Handbook 537. Washington, D.C.

35. Zhou, W. and B. Wu. 2008. Assessment of soil erosion and sediment delivery ratio using remote sensing and GIS: a case study of upstream Chaobaihe River catchment, north China. Inter. J. Sediment Res. 23(2): 167-173. 


\title{
Investigation of Soil loss from Small Plots with Different Soil Textures in Sequential Simulated Rainfall Events
}

\author{
A. R. Vaezi ${ }^{*}$ and H. Hasanzadeh ${ }^{1}$
}

(Received: Aug. 5-2012; Accepted : Jan. 5-2016)

\begin{abstract}
Knowledge of variation in soil properties from each event to another is very important for the determination of critical periods during which soil is susceptible to erosion processes. This study was carried out to investigate soil loss in sequential rainfall events in Zanjan Province. Toward this, ten soil textures samples were taken and were transported to small plots $(60 \mathrm{~cm} \times 80 \mathrm{~cm})$ with 20 -cm depth) on a $8 \%$ slope land at three replications. The plots were exposed to ten simulated rainfalls with an intensity of $55 \mathrm{~mm} \mathrm{~h}^{-1}$ for 30-min and 5-day intervals. A total of 300 simulated rainfall trials were carried out at the plots. Results indicated that soil moisture, runoff production and soil loss were significantly affected by rainfall events $(\mathrm{P}<0.001)$. Increasing soil moisture and consequently decreasing soil infiltration capacity were the most crucial element in increasing runoff production and soil loss in the sequential rainfall events, in a way that about $84 \%$ of soil loss variation in the rainfall events could be explained based on antecedent soil moisture. After the fifths rainfall event, no significant differences was found in soil infiltration capacity as well as runoff production because of soil moisture reaching to the water-holding capacity. Nevertheless, an increasing trend was observed in soil loss after fifth event which could associate with presence of more erodible soil particles on the surface and consequently increasing the concentration of surface flows.
\end{abstract}

Keywords: Simulated rainfall, Antecedent soil moisture, Runoff, Soil infiltration rate, Soil erosion processes.

1. Dept. of Soil Sci., Agric. Faculty, Univ. of Zanjan, Zanjan, Iran.

*: Corresponding Author, Email: vaezi.alireza@gmail.com, vaezi.alireza@znu.ac.ir 